\title{
SuPRAGINGIVAL CALCUlus: Formation AND CONTROL
}

\author{
Ye Jin \\ Hak-Kong Yip* \\ Graduate Student, Faculty of Dentistry, the University of Hong Kong, Hong Kong; *Faculty of Dentistry, The University of Hong Kong, Prince Philip Dental Hospital, PPDH 1A23, 34 Hospital Road, \\ Hong Kong, P.R. China; *corresponding author, hkyip@ hkusua.hku.hk
}

\begin{abstract}
Dental calculus is composed of inorganic components and organic matrix. Brushite, dicalcium phosphate dihydrate, octacalcium phosphate, hydroxyapatite, and whitlockite form the mineral part of dental calculus. Salivary proteins selectively adsorb on the tooth surface to form an acquired pellicle. It is followed by the adherence of various oral micro-organisms. Fimbriae, flagella, and some other surface proteins are essential for microbial adherence. Microbial co-aggregation and co-adhesion enable some micro-organisms, which are incapable of adhering, to adhere to the pellicle-coated tooth surface. Once organisms attach to the tooth surface, new genes could be expressed so that mature dental plaque can form and biofilm bacteria assume increased resistance to antimicrobial agents. Supersaturation of saliva and plaque fluid with respect to calcium phosphates is the driving force for plaque mineralization. Both salivary flow rate and plaque $\mathrm{pH}$ appear to influence the saturation degree of calcium phosphates. Acidic phospholipids and specific proteolipids present in cell membranes play a key role in microbial mineralization. The roles of crystal growth inhibitors, promoters, and organic acids in calculus formation are discussed. Application of biofilm culture systems in plaque mineralization is concisely reviewed. Anti-calculus agents used-centering on triclosan plus polyvinyl methyl ether/maleic acid copolymer, pyrophosphate plus polyvinyl methyl ether/maleic acid copolymer, and zinc ion-in commercial dentifrices are also discussed in this paper.
\end{abstract}

Key words. Dental calculus, plaque mineralization, microbial mineralization, organic acid, anti-calculus agent.

\section{(I) Composition and Structure of Dental Calculus}

D ental calculus is primarily composed of mineral as well as inorganic and organic components. Supragingival and subgingival calculus contain $37 \%$ and $58 \%$ mineral content by volume, respectively (Friskopp and Isacsson, 1984). The matrix of supragingival calculus constitutes $15.7 \%$ of the calculus dry weight and contains $54.9 \%$ protein and $10.2 \%$ lipid. Of the total lipids, $61.8 \%$ are neutral lipids, including a high content of free fatty acids and a smaller amount of triglycerides. Glycolipids account for $28 \%$ of the total lipids and are composed of $17.2 \%$ simple glycosphingolipids, mainly lactosyl- and glucosylceramine, and of $82.8 \%$ neutral and sulfated glyceroglucolipids. Phospholipids, representing $10.2 \%$ of the total lipid, contain $34.2 \%$ phosphatidylethanolamine, $25.5 \%$ diphosphatidylglycerol, $2.3 \%$ phosphatidylinositol, and 1.7\% phosphatidylserine. Phosphatidylinositol and phosphatidylserine are two important classes of acidic phospholipids but are only minor phospholipid components of bacterial cell membrane (Goldfine, 1972), which are enriched in phosphatidylethanolamine and diphosphatidylglycerol (neutral phospholipids) (Bishop, 1971). Notably, dental calculus contains both total phospholipids and acidic phospholipids in much higher concentrations than parotid saliva (Mandel and Eisenstein, 1969; Slomiany et al., 1981). In addition, the concentration of phospholipids in the saliva of heavy calculus formers is significantly higher than that of light calculus formers (Slomiany et al., 1981). These findings suggest that phospholipids play an important role in calculus formation (discussed in a later section).

Dental calculus is always covered by a soft and loose layer of micro-organisms. On supragingival calculus, this layer is dominated by filamentous micro-organisms. The filaments are approximately perpendicular to and in direct contact with the underlying dense calculus. By contrast, the mixture of cocci, rods, and filaments covering subgingival calculus has no distinct pattern of orientation (Friskopp and Hammarström, 1980). After treatment with sodium hypochlorite, however, the filaments on the surface of supragingival calculus disappear and, in scanning electron microscopy (SEM), the supragingival calculus has a honeycomb appearance (Friskopp and Hammarström, 1980). Sodium-hypochlorite-washed subgingival calculus shows holes in the surfaces which are less regular than those in the surfaces of the supragingival calculus (Friskopp and Hammarström, 1980). Beneath the layer of micro-organisms are calcifying areas, which appear to be laminated due to alternating dark- and light-staining bands (Mandel et al., 1957). The properties of dental calculus were further investigated by Friskopp (1983), who reported that the calcifying areas of supragingival calculus are heterogeneous due to the presence of non-calcified layers. These non-calcified layers are usually irregular, resembling bands of cavities partially separated by calcified materials. Additionally, it has been demonstrated that plaque mineralization occurs in numerous individual foci (Mandel et al., 1957; Friskopp, 1983). Mineral deposits of dental calculus are present both between and within micro-organisms, depending upon deposit age (Donald, 1997); that is, mineral initially deposits in the matrix of plaque, and gradually some plaque micro-organisms become calcified with increasing age of calculus.

It has been demonstrated that octacalcium phosphate $\left[\mathrm{Ca}_{8}\left(\mathrm{PO}_{4}\right)_{4}\left(\mathrm{HPO}_{4}\right)_{2} 5 \mathrm{HO}\right](\mathrm{OCP})$, hydroxyapatite $\left[\mathrm{Ca}_{10}\left(\mathrm{PO}_{4}\right)_{6}\right.$ $\left.(\mathrm{OH})_{2}\right](\mathrm{HAP})$, and $\beta$-tricalcium phosphate or whitlockite $\left[\mathrm{Ca}_{10}\left(\mathrm{HPO}_{4}\right)\left(\mathrm{PO}_{4}\right)_{6}\right]$ (WHT) form the inorganic part of both supragingival and subgingival calculus. Brushite $\left[\mathrm{CaHPO} \mathrm{P}_{4}^{-}\right.$ $2 \mathrm{H}_{2} \mathrm{O}$ : dicalcium phosphate dihydrate] (DCPD) is present only in the early-stage supragingival calculus (Rowles, 1964). 
Of the calcium phosphate crystals mentioned above, only WHT contains magnesium, which may substitute for part of the calcium in WHT (Friskopp and Isacsson, 1984). Supragingival and subgingival calculus differ from each other with respect to the principal crystal constituents and inorganic elemental components; that is, the WHT-to-HAP (Jensen and Danø, 1954) and calcium-to-phosphorus ratios (Little and Hazen, 1964) in supragingival calculus are lower than those in subgingival calculus.

\section{(II) The Distribution of Dental Calculus in the Dentition}

It is well-known that the greatest amount of supragingival calculus is present on the lingual surfaces of mandibular anterior teeth and decreases toward the third molars (Parfitt, 1959). In the maxilla, supragingival calculus frequently forms on the buccal surfaces of the first molars (Parfitt, 1959). In both the mandible and maxilla, these are sites that are close to the orifices of salivary ducts.

Subgingival calculus also exhibits site-specificity, although it is much less apparent than that of its supragingival counterpart (Corbett and Dawes, 1998). It has been reported that the levels of subgingival calculus are significantly higher on the lingual than on the buccal surfaces. For the lingual surfaces of the teeth, the lower first molars have the most subgingival calculus. For the buccal surfaces of the teeth, the mandibular anterior teeth and maxillary molar teeth have the greatest amount of subgingival calculus.

For the mouth as a whole, significant associations $(\mathrm{P}<$ 0.001 ) have been demonstrated between the levels of supraand subgingival calculus, between the levels of supragingival calculus on buccal and lingual surfaces, and between the levels of subgingival calculus on buccal and lingual surfaces. For individual teeth, however, only a few teeth exhibit the above associations (Corbett and Dawes, 1998).

Saliva is closely associated with the distribution pattern of supragingival calculus. As Collins and Dawes (1987) have suggested, saliva is present in the mouth not as a bulk volume but as a mobile film of $0.1 \mathrm{~mm}$ average thickness. For unstimulated salivary flow, the velocity of the film over tooth surfaces is estimated to vary between 0.8 and $8 \mathrm{~mm} / \mathrm{min}$, depending on different oral regions and status of saliva; for stimulated salivary flow, the velocity is from 1.3 to about 350 $\mathrm{mm} / \mathrm{min}$ (Dawes et al., 1989). The lowest film velocity of 0.8 to $1.3 \mathrm{~mm} / \mathrm{min}$ occurs on the facial surfaces of the upper incisors, while the highest salivary film velocities are observed on the lingual surfaces of teeth (Dawes et al., 1989). Based upon these results, it can be concluded that saliva is neither evenly mixed nor well- distributed in the mouth. The site-specificity distribution of calculus can be therefore explained as follows. Parotid and submandibular saliva is supersaturated with respect to calcium phosphates (Lagerlöf, 1983) and is in contact with plaque on the lingual surfaces of the lower incisors and the facial surfaces of the upper molars. As discussed in a later section on urea metabolism, the abundant supply of urea from the major salivary gland secretions tends to increase the $\mathrm{pH}$ in plaque (Sissons et al., 1994a) and promote calcium phosphate precipitation. Furthermore, the high salivary film velocity promotes clearance of salivary sugar and acid from plaque and leads to a higher resting plaque $\mathrm{pH}$. More supragingival calculus thus occurs in the regions with the most exposure to saliva. On the facial sur- faces of upper anterior incisors, the salivary film velocity is low so that the supply of calcium phosphates and urea is limited and sugar and acid easily accumulate in plaque. In summary, calculus deposition tends to occur where plaque is exposed to a salivary film of high velocity.

\section{(III) Mechanism of Plaque and Microbial Mineralization}

Following tooth eruption or a dental prophylaxis, salivary proteins rapidly and selectively adsorb onto the enamel surface to form an acquired enamel pellicle. It is followed by the adherence of various oral micro-organisms. Gram- positive coccoidal organisms are the first settlers to adhere to the formed enamel pellicle, and subsequently, filamentous bacteria gradually dominate the maturing plaque biofilm (Scheie, 1994).

Plaque absorbs calcium and phosphate from saliva for the formation of supragingival calculus and from crevicular fluid for the formation of subgingival calculus. Calcium phosphate supersaturation, certain membrane-associated components, and the degradation of nucleation inhibitors are required for initial mineralization of plaque and bacteria. Calculus formation begins with the deposition of kinetically favored precursor phases of calcium phosphate, OCP and DCPD, which are gradually hydrolyzed and transformed into less soluble HAP and WHT mineral phases (Rowles, 1964).

\section{(A) AdSORPTION OF SALIVARY PROTEINS}

Three types of time-dependent adsorption of salivary proteins have been observed (Lamkin et al., 1996). Some salivary proteins, such as proline-rich protein-3 (PRP-3), PRP-4, and statherin, adsorb very fast onto HAP, whereas the binding rate of -amylase, glycosylated proline-rich protein (PRG), and cystatins is slow. The third type of protein adsorption can be seen in the case of PRP-1, PRP-2, and histatins. It is characterized by a two-step process-a rapid adsorption (the direct binding of proteins to HAP), followed by a slow adsorption (protein-protein interactions). Studies on the adsorption of acidic PRPs and statherins appear frequently in the literature. Acidic PRPs and statherins possess polarity because of their highly charged amino-terminal domains, which are responsible for the adsorption of these proteins onto a tooth surface. The phosphoserine residues in the charged regions are believed to be essential for the electrostatic interactions (Raj et al., 1992).

As on the tooth surface, acquired pellicle forms on an implant surface when the metal surface initially comes into contact with tissues (Baier, 1982). The acquired pellicle on an implant surface attracts and harbors various oral bacteria, which may account for the occurrence of implantitis. Notably, the adsorption of proteins does not occur on the surface of pure titanium (Ti). It is demonstrated that a 5- to 6-nm oxide layer composed of $\mathrm{TiO}_{2}$ forms on the surface of $\mathrm{Ti}$ when the implant surface is exposed to air. The physicochemical characteristics of $\mathrm{TiO}_{2}$ are quite different from those of pure $\mathrm{Ti}$; at physiological $\mathrm{pH}$, the $\mathrm{TiO}_{2}$ layer carries net negative charges, which enable the $\mathrm{TiO}_{2}$ layer to bind cations like $\mathrm{Ca}^{2+}$ (Abe, 1982). The bound $\mathrm{Ca}^{2+}$ makes the surface of an implant positively charged and, consequently, attracts the high-weight molecules carrying negative charges, notably proteins. Ti pellicle differs from enamel pellicle. It has been found that although Ti pellicle contains high-molecular-weight mucin and -amylase that are also present in enamel pellicle, it lacks cystatins and low-molecular-weight mucin (Fisher et al., 1987). 
Three types of protein adsorption onto implant surfaces have been proposed (Williams and Williams, 1988). Protein adsorption onto the surfaces of $\mathrm{Ti}, \mathrm{Al}, \mathrm{Mo}, \mathrm{Ni}, \mathrm{Ta}$, and $\mathrm{Al}_{2} \mathrm{O}_{3}$ implants is slow and will stop a few hours later when a single layer of protein molecules forms on the implant surfaces. The adsorption of proteins onto $\mathrm{V}$ and $\mathrm{TiO}_{2}$ is also slow but continuous. The continuous adsorption can be explained by the possibility that after a single layer of protein molecules forms on the implant surfaces, additional proteins adhere to the attached ones. If the protein adsorption is not only continuous but also fast, it is likely that multi-layers of proteins will form on the implant surfaces.

\section{(B) Microbial ADHERENCE}

As Van Loosdrecht et al. (1990) and Bollen et al. (1996) have described, the microbial adhesion to solid surfaces (such as tooth surfaces and various implant surfaces) may proceed as a four-stage sequence. The first stage is the initial approach of bacteria to a surface where random contact, such as Brownian motions and liquid flow, or active movement of micro-organisms may occur. The attractive van der Waals' forces and repulsive electrostatic forces are responsible for the second stage of microbial adhesion, which is a reversible process. The firm attachment of micro- organisms, "the third stage', is irreversible and is followed by the fourth stage of adhesion, i.e., bacterial colonization.

\section{(1) Surface proteins and bacterial adherence}

Appendages, such as fimbriae or pili, emerging from the cell surfaces of many micro-organisms, are involved in the bacterial adherence to pellicle-coated tooth surfaces. The extension and retraction of Pseudomonas aeruginosa type IV fimbriae (pili) have been reported to produce forces that propel bacteria across a surface. This phenomenon is referred to as twitching motility (Darzins, 1994). P. aeruginosa strains with mutations in pilB, pilC, and pilY1, the genes required for the synthesis of type IV fimbriae (pili) (Nunn et al., 1990), form a monolayer of cells only on an abiotic surface and are incapable of forming microcolonies. Fimbriae may also serve as adhesins for various receptors in the bacterial adhesion process. For example, $P$. gingivalis fimbriae can interact with human salivary components, such as PRPs and statherins (Amano et al., 1996). There exist three or more binding sites in fimbrillin proteins of bacteria, and the combination of all these binding sites would be essential for stable binding of salivary proteins (Amano et al., 1996).

Flagellum, another microbial surface protein, is also involved in microbial adherence. It was found that few if any strains carrying a mutation in flaK, the gene required for the synthesis of flagellum, attach to the abiotic surface, indicating a role of flagella and/or motility in the initial cell-to-surface interactions (O'Toole and Kolter, 1998).

Flagella may have four different functions. First, flagella may be involved in chemotaxis and enable planktonic bacteria to swim toward nutrients associated with a surface or signals generated by cells attached to a surface. Second, flagellamediated motility may overcome repulsive forces at the medium-surface interface, to allow the bacteria to reach the surface. Third, flagella-mediated motility may be required for the bacteria within a developing biofilm to move along the surface, thus facilitating growth and spread of the biofilm. Finally, flagella per se may be required for biofilm formation by adhering to an abiotic surface (Pratt and Kolter, 1998). In an Escherichia coli model system, mutations that inhibit each of these aspects of flagella function were used to determine which aspect was critical for biofilm formation. The results showed that motile cells that were non-chemotactic formed biofilm indistinguishable from their wild-type counterpart. In contrast, cells either lacking flagella or possessing paralyzed flagella were severely defective in biofilm formation (Pratt and Kolter, 1998). It is therefore evident that chemotaxis is dispensable for biofilm formation, whereas flagella-mediated motility is critical for this process.

Collectively, flagella-mediated motility enable the bacteria to reach a distance short enough from a surface by overcoming the electrostatic interface repulsion so that fimbriae (pili) can push them onto the surface via adhesin- receptor interactions and/or twitching motility. The attached bacteria can move along the surface propelled again by the flagellagenerated force.

In addition to fimbriae and flagella, many other surface proteins are also involved in bacterial adherence. Streptococcus mutans surface proteins have been most widely investigated. P1, a 117-kd and a 127-kd protein, and two glucosyltransferases (GTFase) appear to inhibit the adherence of S. mutans WD9463A (c) competitively to an acquired-pelliclecoated surface (Zhan et al., 1998). These results indicate that the above surface proteins serve as adhesins for specific receptors on acquired pellicle. In contrast, Zhan et al. (1998) found that another GTFase improved the bacterial adherence, indicating that this GTFase may adsorb onto the HAP surface first and then become the receptor for $S$. mutans. An alternative possibility is that it promotes bacterial adherence by altering the properties of acquired pellicle (Zhan et al., 1998). Based upon these findings, it can be concluded that a surface protein contributes to the bacterial adherence by its specific mechanism.

\section{(2) Microbial co-aggregation and coadhesion}

Oral bacteria tend to associate with one another. In suspension, the association between different oral bacteria is termed "co-aggregation", while it is referred to as co-adhesion if one partner of the pair is attached to a surface. Microbial co-adhesion would be of great importance for the colonization of oral micro-organisms on tooth surfaces. For instance, Streptococcus sanguis strains facilitate the adherence of Actinomyces naeslundii, which per se possess poor adhesive ability (Ganeshkumar et al., 1991).

Lectin-sugar interaction is involved in co-aggregation of bacteria, which can be inhibited by sugars (McIntire et al., 1978). Lectin-sugar interaction also contributes to co-aggregation between yeast and bacteria (Ganeshkumar et al., 1991); the sugars in the mannoprotein-containing capsule surrounding the yeast cell may associate with bacteria and human epithelial cells by a lectin-like interaction.

Adhesin-receptor interaction also has a role in microbial co-aggregation. The adhesin molecule on the surface of one partner cell and the receptor molecule on the surface of the other partner cell have to be complementary for a specific binding interaction to occur (Simmonds et al., 2000). Numerous genes encoding the adhesin molecules have been cloned and sequenced, and the encoded proteins have been investigated. For instance, Ssp, a major streptococcal surface protein, mediate adhesion to Porphyromonas gingivalis via a C- 
terminal functional domain (Brooks et al., 1997).

Co-aggregation between some pairs appears to be cationdependent. For example, calcium ion is required for co- aggregation reactions between actinomycete (such as Actinomyces viscosus and A. naeslundii) and streptococcal cells (such as $S$. sanguis and Streptococcus mitis) (Cisar et al., 1979). Since the surfaces of most bacteria are negatively charged, it is not surprising that electrostatic repulsion exists between bacteria. Cations may therefore make the bacterial zeta potentials less negative, and consequently the weakened electrostatic repulsion allows co-aggregation to occur. Co-aggregation between bacteria can also be non-cation-dependent, such as the co-aggregation of Prevotella intermedia and Prevotella nigrescens with A. naeslundii (Cookson et al., 1995), which can be explained by surface thermodynamic analysis based on interfacial free energies.

In addition to cations, extracellular vesicles also have a role in bacterial co-aggregation (Grenier and Mayrand, 1987). $P$. gingivalis-released vesicles, which have been reported to agglutinate sheep erythrocytes strongly, can promote the coaggregation of Eubacterium saburreum and Capnocytophaga ochracea, which otherwise cannot co-aggregate. Electron microscopy reveals that these vesicles act as a physical link or bridge between the two bacterial cells. The vesicle-mediated co-aggregation is unaffected by variation in $\mathrm{pH}$ from 4.5 to 8.5 , the presence of sugars, uronic acids at a concentration of 100 $\mathrm{mM}$, or EDTA at a concentration of $10 \mathrm{mM}$. L-arginine and Llysine, however, are able to inhibit these co-aggregations mediated by vesicles (Grenier and Mayrand, 1987).

Non-specific interaction between micro-organisms is another mechanism of co-aggregation and co-adhesion. For instance, cell-surface lipoproteins are responsible for the nonspecific adhesive interaction of Streptococcus gordonii with other bacterial species (Jenkinson, 1992).

\section{(3) New behavior pattern of attached bacteria}

Once attached to a surface, bacteria stop dividing for hours, during which time genetic changes occur in the planktonic cells, and a biofilm phenotype comes into existence (Rice et al., 2000 ). With the passage of time, a process termed cell-densitydependent gene expression is required for the formation of more mature biofilm. In Gram-positive bacteria, cell-densitydependent gene expression proceeds as follows. With increasing numbers of bacteria, the pheromone (signal molecules) accumulates up to a critical threshold. The signal is received by the sensing component of a two-component signal transduction system (Kleerebezem et al., 1997). The second component of the transduction system is a cognate response regulator, which is activated by the sensing component and initiates the expression of target genes (Morrison, 1997). Take S. gordonii as an example. ComD, an autophosphorylating histidine kinase, is the sensing component that acts as a receptor for Com C, the pheromone that induces competence in a bacterial population. ComE serves as the response regulator, which receives the phosphoryl group from Com $\mathrm{D}$ and then binds to specific promoter regions of appropriate target genes (Morrison, 1997). When the level of the molecule approaches a critical point, a transcriptional activator is triggered and expression of the target gene occurs, which is followed by a new behavior pattern of oral bacteria. In the process of celldensity-dependent gene expression, the required concentration of signal molecules depends on the critical level of bacterial population density. The sensing process is therefore referred to as a quorum sensing system (Pulcini, 2001).

While ComD acts as a signal molecule for Gram-positive bacteria, N-acyl homoserine lactone is involved in the cell- tocell signaling system as a signal molecule for most Gram-negative bacteria (Pulcini, 2001). Many studies have been conducted to explore the cell-density-dependent gene expression of Gram-negative P. aeruginosa. There are at least two signals in $P$. aeruginosa serving the cell-to-cell signaling system, lasRlasI and rhlR-rhlI (vsmR-vsmI) systems (Davies et al., 1998). The Ias I gene product directs the synthesis of a diffusible extracellular signal, $\mathrm{N}$-(3- oxododecanoyl)-L-homoserine lactone $\left(3 \mathrm{OC}_{12}\right.$-HSL). When $3 \mathrm{OC}_{12}$-HSL reaches a critical level, the lasR product activates the IasI and rhlR-rhlI system. The rhlI product directs the synthesis of another signal molecule, $\mathrm{N}$ butyryl-L-homoserine lactone. A sufficient level of N-butyrylL-homoserine lactone is required by the $r h l R$ gene product for the expression of target gene. Research has shown that IasI is essential for biofilm differentiation, resistance to antimicrobial agents, and secretion of an extracellular polysaccharide (EPS) matrix that differs from the planktonic cell matrix (Davies et al., 1998).

Biofilm bacteria exhibit stronger resistance to biocides and antimicrobial agents than does their planktonic counterpart. Four hypotheses may help to explain the increased resistance. First, the exopolysaccharide of the biofilm matrix may inhibit the diffusion of biocides and antimicrobial agents. Second, the physiological differences among biofilm bacteria leave only part of biofilm bacteria susceptible to growth-dependent antibiotics. Third, the genetic changes occurring in transition from planktonic to biofilm bacteria make the biofilm bacteria insensitive to various biocides and antimicrobial agents (Pulcini, 2001). Finally, the low level of metabolisms due to nutrient limitation may also contribute to the resistance to antimicrobial agents by biofilm bacteria (Chen, 2001).

\section{(4) Microbial adherence to implant surfaces}

Microbial adherence to Ti implant surfaces has been investigated in various studies (Nakazato et al., 1989; Edgerton et al., 1996). Since Ti pellicle differs from enamel pellicle with regard to protein composition, it is understandable that the microbial adherence and the subsequent microbial colonization on a Ti surface may be different from that on an enamel surface (Edgerton et al., 1996). Indeed, there is evidence that $\mathrm{Ti}$ implants harbor less mature plaque, which is composed of more coccoid cells and fewer motile rods, as compared with natural teeth (Quirynen and Listgarten, 1990). In addition, Nakou et al. (1987) found six species of oral bacteria unique to dental implants. Microbial adherence to an implant surface can be promoted by an increase in the roughness of the implant surface. Higher levels of microbial adherence have been found on rough Ti surfaces than on smooth and polished surfaces in in vivo studies (Nakazato et al., 1989).

\section{(C) THE DRIVING FORCE FOR PLAQUE MINERALIZATION}

Calcium and phosphate are two salivary ions which are "raw materials" for dental calculus formation. Theoretically, supersaturation of saliva, especially plaque fluid, with respect to calcium phosphate salts is the driving force for dental plaque mineralization. Ion product (Ip) and solubility product (Ksp) are important for estimation of saturation degree (SD) with 
respect to a given salt. If Ip $>\mathrm{Ksp}$, the fluid is supersaturated and precipitation of the salt can occur; if Ip = Ksp, the fluid is just saturated with respect to the salt, and if Ip $<\mathrm{Ksp}$, the salt tends to dissolve, since the fluid is not saturated with respect to the salt (Dawes, 1998). As a matter of fact, parotid and submandibular saliva is generally supersaturated with respect to HAP, OCP, and WHT (Lagerlöf, 1983). Submandibular secretions are even more highly supersaturated with respect to HAP than are parotid secretions. Like saliva, rested and starved plaque fluids are also supersaturated with respect to HAP and other calcium phosphate phases (Carey et al., 1986). $\mathrm{HAP}$ is the least soluble phase at $\mathrm{pH}$ values above about 4.0, and its solubility varies more quickly with $\mathrm{pH}$ than DCPD (Barone and Nancollas, 1978). Therefore, saliva and plaque fluid are more supersaturated with respect to HAP, and consequently, the precipitation of HAP is more likely to occur compared with other calcium phosphate phases. In a recent study (Poff et al., 1997), however, it was reported that no significant correlation existed between calcium phosphate supersaturation in saliva and the rate of calculus formation for both unstimulated and stimulated saliva. However, calculus formation is influenced by a variety of factors, such as salivary flow rate, and inhibitors and promoters of calculus formation, other than salivary supersaturation with calcium phosphate salts. Unfortunately, all these factors were not controlled in this study. Therefore, there is an inherent limitation in the study by Poff et al. in vivo (1997). The lack of correlation between the degree of supersaturation and calculus formation may result from the effects of these factors. For example, if the subjects in one group have a higher degree of supersaturation with respect to calcium phosphates but lower salivary flow rate compared with those in the other group, the two groups may have similar calculus levels; that is, the correlation between the degree of supersaturation and calculus formation is overshadowed by the inter-group difference in salivary flow rate.

Salivary flow rate affects calcium phosphate saturation in glandular saliva. According to a study by Lagerlöf (1983), although parotid saliva is supersaturated with respect to HAP and WHT at all flow rates tested, ranging from 0.1 to 2.0 $\mathrm{mL} / \mathrm{min}$, parotid saliva is undersaturated with OCP at flow rates lower than $0.2 \mathrm{~mL} / \mathrm{min}$. With respect to DCPD, parotid saliva is undersaturated or just saturated at all flow rates, and the degree of saturation is only weakly influenced by flow rate. The higher salivary $\mathrm{pH}$ or possibly the increased secretions of calcium phosphate salts in glandular saliva may contribute to the effect of salivary flow rate on the degree of calcium phosphate saturation in saliva.

The effect of $\mathrm{pH}$ on calcium phosphate saturation degree in parotid saliva has also been investigated (Lagerlöf, 1983). As Lagerlöf reported, the degree of saturation with respect to $\mathrm{HAP}, \mathrm{OCP}$, and DCPD increased with increasing salivary $\mathrm{pH}$ at various flow rates. The parotid saliva was supersaturated with respect to HAP, WHT, and OCP at $\mathrm{pH}$ values above 5.5, 6.4 , and 6.9, respectively. A close correlation $(\mathrm{r}=0.91)$ between salivary $\mathrm{pH}$ and degree of supersaturation was observed by Poff et al. (1997). Take HAP, for example. The next equation shows why the degree of calcium phosphate saturation is influenced by $\mathrm{pH}: \mathrm{Ca}_{10}\left(\mathrm{PO}_{4}\right)_{6} \leftrightarrow(\mathrm{OH})_{2} 10 \mathrm{Ca}^{2+}+6 \mathrm{PO}_{4}^{3-}+2 \mathrm{OH}^{-}$. When the calcium phosphate crystals in solution are in kinetic equilibrium, the rate of precipitation is equal to that of dissolution. If $\mathrm{pH}$ in solution drops (the concentration of hydrogen ions increases), $\mathrm{OH}^{-}$and $\mathrm{PO}_{4}{ }^{3-}$ tend to be removed by $\mathrm{H}^{+}$by forming water and more acidic forms of phosphate, respectively. As a result, the equilibrium is broken and is pulled to the right; that is, the rate of dissolution exceeds that of precipitation, and the net result is the dissolution of HAP crystals and a decrease in the HAP saturation degree. If $\mathrm{pH}$ in solution rises, the opposite event will occur: $\mathrm{OH}^{-}$forces the equilibrium in the equation to the left, thus resulting in an increased degree of HAP saturation in solution (Cotton and Wilkinson, 1966).

\section{(D) THE INVOLVEMENT OF BACTERIA IN CALCULUS FORMATION}

Although calculus can be induced in germ-free animals (Theilade et al., 1964), human calculus development invariably involves plaque bacterial calcification. In vitro mineralization in specific plaque bacteria has been observed by various studies. Microbial mineralization occurs even within "acidogenic" and cariogenic bacteria (Moorer et al., 1993). Studies have shown that filamentous micro-organisms are predominant in supragingival calculus and calculus- associated plaque, whereas micro-organisms of various morphologies are found in the plaque adjacent to subgingival calculus (Friskopp and Hammarström, 1980). In addition to dead micro-organisms, live and degenerated ones can also calcify in synthetic calcifying media (Sidaway, 1980). Additionally, deoxyribose and ribose have never been found in calculus, suggesting the absence of nucleic acids in calculus (Little et al., 1966). The lack of nucleic acids in calculus indicates that the oral micro-organisms undergo extensive degradation, leaving only the cell walls for calculus formation.

Importantly, some oral bacteria seem to be associated with the absence of calculus. Pockets harboring undetectable subgingival calculus deposits appeared to have a significantly greater percentage of coccoid forms and fewer motile rods and total motile morphotypes (CM Brown et al., 1991). In addition, non-calculus sites are associated with a significantly higher level of Actinobacillus actinomycetemcomitans $(A a)$ and a lower level of black-pigmented anaerobic rods than sites presenting with calculus. Aa has, therefore, been proposed to exert an inhibitory effect on the colonization of plaque-producing and calcifiable bacteria (Listgarten, 1987).

\section{(E) Microbial Mineralization}

It has been reported that initial deposition of apatite in calcifying bacteria is associated with membrane or acidic membrane-associated components (Boyan and Boskey, 1984). Although the levels of acidic phospholipids, principally phosphatidylserine and phosphatidylinositol, are generally low in biologic membranes compared with some other lipids, acidic phospholipids are the key components of the membranes involved in microbial calcification. Acidic phospholipid has a net negative charge at physiological pH and is amphipathic, with a hydrophobic tail and a hydrophilic head, so that either a spherical micelle or a bilayer can be formed, depending upon the type of molecule involved (Vogel and Boyan-Salyers, 1976). The functions of acidic phospholipids in calcification depend upon their ability to bind calcium by their negatively charged groups. Calcium is bound to adjacent phospholipid molecules in the membrane through a two-point electrostatic attachment to form a stern layer which facilitates the interaction of calcium with inorganic phosphate ions in solution (Hauster et al., 1969). The bound calcium ions can cause 
loss in water of hydration due to the neutralization of electrostatic charge of membrane (Hauster et al., 1975). Desolvation helps to concentrate calcium and phosphate ions, thus facilitating their interactions. Inorganic phosphate associates with the bound calcium to form a Caphospholipid-phosphate complex (CPLX). Once CPLX has formed, apatite deposition follows when sufficient calcium and phosphate ions are present and the concentration of inhibitors is low. The availability of CPLX exhibits bacterium-specificity; CPLX is always present in Corynebacterium matruchotii whether or not they are cultured in calcification-permissive media, while CPLX is absent from bacteria that do not calcify in culture (Boyan and Boskey, 1984). Moreover, not all of the acidic phospholipids are involved in the formation of CPLX, and phosphatidylserine is the predominant acidic phospholipid in CPLX isolated from $C$. matruchotii.

However, acidic phospholipids not associated with specific proteolipids in the membrane neither form CPLX nor support HAP deposition. It has been shown that when various lipid extracts from C. matruchotii are incubated in metastable calcium phosphate solutions, CPLX formation occurs predominantly on proteolipid-associated phospholipids (Boyan and Boskey, 1984). Calcifiability of bacteria is positively correlated with the increasing concentration of proteolipids. Further, the membrane-associated proteolipid purified from C. matruchotii can induce calcium precipitation in vitro (Van Dijk et al., 1998). These observations suggest that acidic phospholipids must associate with specific non-polar protein to form a proteolipid complex, through hydrophobic interactions, to initiate calcification. Moreover, although all micro-organisms have proteolipids, not all micro-organisms calcify, suggesting a diversity in bacterial proteolipids. For example, proteolipids isolated from $A$. naeslundii, which are different in concentration and composition from those isolated from C. matruchotii, do not calcify in culture (Howell and Boyan- Salyers, 1980). This is consistent with the observation discussed above that not all the bacteria can form CPLX. Additionally, the amount of proteolipids has been observed to increase with culture time, and this finding partially explains the observation that there is a maturation of plaque before calcification can take place (Mandel, 1957).

The transport of ions through cell membrane is much faster than that predicted by the solubility constants of ions in lipids, suggesting that ions may be transported across biological membranes through ion channels within the phospholipid bilayer (Benga and Holmes, 1984). Proteolipid proteins exhibit conformational flexibility, which may contribute to their capacity to form ion channels in phospholipid bilayers. It has been demonstrated that protein ion channels are composed of several membranes spanning $\alpha$-helixes and that these $\alpha$-helixes are amphiphilic, with a hydrophilic face and a hydrophobic face. The $\alpha$-helixes are parallel, and their hydrophilic faces aggregate to form an ion channel (Lear et al., 1988). A 10,000 $\mathrm{M}_{\mathrm{r}}$ proteolipid and an $8500 \mathrm{M}_{\mathrm{r}}$ dicyclohexylcarbodiimide-binding proteolipid have been proposed to be two components of the ion channel (Swain and Boyan, 1989). Collectively, proteolipids may function not only as sites for CPLX formation but also as ion channels for transport of calcium and phosphate to the calcification sites or of protons away from the sites.

Lipids are also responsible for the calcification of dental calculus matrix. It has been known that although membranes are mainly cellular constituents, either as the plasma membranes or as intracellular structures, membranes are also present in extracellular matrix of calcifying tissues in the form of matrix vesicles produced by a budding off the plasma membranes or by extrusion (Wuthier and Cummins, 1974). Therefore, the calcifiable proteolipids in the membranes of matrix vesicles can initiate the mineralization process in the calculus matrix as they do in calcifying bacteria.

\section{(F) NUCLEATION INHIBITORS}

It has been demonstrated that magnesium (Mg) prevents apatite nucleation by $C$. matruchotii proteolipid during incubation in a metastable calcium phosphate solution. At a level that does not alter calcium binding by C. matruchotii proteolipid, Mg blocks apatite crystallization and stabilizes calcium phosphate as amorphous mineral (Ennever and Vogel, 1981). Diphosphonates, such as ethane-1-hydroxy-1, 1-Diphosphonate (EHDP), inhibit both apatite nucleation (Fleisch et al., 1970) and crystal growth (Francis, 1969). Importantly, nucleation inhibitors should not be used clinically, because they have been found to interfere with normal mineralization of hard tissues (Schenk et al., 1973).

\section{(G) Crystal growth inhibitors}

Some salivary proteins containing negatively charged sequences may adsorb at active sites on the crystallite surfaces and thereby inhibit the growth and dissolution of calcium phosphate crystals. Of these negatively charged salivary proteins, statherin and PRP are two representatives of salivary inhibitors of crystal growth.

It is notable that macromolecules like PRP cannot completely block crystal growth (Margolis et al., 1982). In an in vitro study by Margolis et al. (1982), the kinetics of crystal growth of HAP was studied with seed crystals of HAP coated with PRP-3 (a proline-rich phosphoprotein salivary inhibitor of crystal growth). In a solution with the nominal composition (1.06 mM in Ca, 0.63 mM in Pi, pH 7.4, $50 \mathrm{mM} \mathrm{NaCl}$ ) as background electrolyte, a saturation degree with respect to HAP of 16.1, and an initial PRP3 concentration of $3.87 \times 10^{-5} \mathrm{~mol} / \mathrm{L}$, PRP should be able to cover $99.9 \%$ adsorption sites available on the surface of HAP, and the application of NaF should not be able to initiate crystal growth. However, when a solution of $\mathrm{NaF}$ (1 ppm) was added, precipitation occurred as evidenced by the continuous decrease of the phosphate concentration. As Margolis et al. (1982) discussed, there may be three explanations for this phenomenon. First, other crystal growth sites are available for the fluoride to induce the formation of fluoridated HAP. Second, PRP-3 and fluoride bind to the same sites, and PRP-3 is displaced from the binding site by fluoride. Third, PRP-3 cannot cover all the available crystal growth sites. To elucidate this issue, Margolis et al. (1982) studied the kinetics of crystal growth of $40 \mathrm{mg}$ HAP seed crystals with $50 \%$ growth sites covered with PRP-3 and $21 \mathrm{mg}$ HAP seed crystals uncovered with PRP-3. After calculation, the number of $50 \%$ growth sites on $40 \mathrm{mg}$ HAP seed crystals was equal to that of $100 \%$ growth sites on $21 \mathrm{mg}$ HAP seed crystals. The results showed that the two groups of HAP seed crystals, in the solutions of various saturation degrees with respect to HAP, exhibited nearly identical kinetic behavior both before and after the addition of $0.75 \mathrm{ppm}$ fluoride. If other crystal growth sites were available for fluoride, the number of these sites on $40 \mathrm{mg}$ HAP seed crystals should have been nearly 
twice that of the sites on $21 \mathrm{mg}$ HAP. When NaF was applied, the growth of $40 \mathrm{mg}$ HAP seed crystals should have been promoted much better than that of $21 \mathrm{mg}$ HAP seed crystals. Thus, the kinetics of crystal growth after the addition of $\mathrm{NaF}$ should have been different. Since the kinetics was identical, the hypothesis of other crystal growth sites for fluoride is rejected. If PRP-3 were displaced from binding sites by fluoride, the growth of $40 \mathrm{mg}$ HAP seed crystals should also have been better promoted by fluoride than that of $20 \mathrm{mg}$ HAP seed crystals. The identical kinetics of crystal growth is best explained by the possibility that at maximum PRP-3 coverage, a small number of crystal growth sites remain uncovered. The two groups of seed crystals have equal numbers of growth sites and therefore exhibit a similar kinetics of crystal growth (Margolis et al., 1982). The incomplete coverage of growth sites by PRP-3 may be due to steric reasons: PRPs are macromolecules, and one PRP molecule will impede the adsorption of other PRP molecules in proximity, thus leaving sites available for crystal growth.

The adsorption sites of PRPs have been investigated by Bennick et al. (1979). They have found that the adsorption sites are located in the proline-poor N-terminal part of PRPs between residues 3 and 25. Further, phosphoserine within the proline-poor $\mathrm{N}$-terminal part may be necessary for optimal adsorption of the proteins to $\mathrm{HAP}$, in that digestion of proteins by phosphatase resulted in considerable decrease in the adsorption by PRP. Additionally, the adsorbed PRP resists proteolytic digestion, since some of the susceptible bonds in the N-terminal part of proteins were protected from digestion by proteolytic enzymes, leaving the proline-rich C-terminal part to be removed gradually.

In addition to PRP and statherin, other salivary molecules with negatively charged residues close to one another may also have a high affinity for apatite surfaces and inhibit crystal growth. Some cystatins in saliva, such as the acidic cystatin $\mathrm{S}$ and the neutral cystatin $\mathrm{SN}$, have several negatively charged residues in their N-termini and thus may be able to bind strongly to HAP. In a study by Johnsson et al. (1991), the adsorption, at HAP surfaces, of these two cystatins was compared with that of statherin. Although the affinity of cystatins for HAP surfaces was lower than that of statherin, their inhibitory effect on crystal growth was considerably greater.

The neutral histatin 1 also has high affinity for apatite surfaces, partly due to the presence of a phosphoserine residue in the vicinity of other negatively charged side-groups in the Nterminal part. The neutral histatin 1 from human parotid saliva has been demonstrated to inhibit crystal growth of HAP (Oppenheim et al., 1986).

Immunoglobulins present in dental plaque and calculus may also have an inhibitory effect on plaque mineralization. The IgG and IgA detected in dental calculus are mainly distributed along the incremental lines, which contain fewer minerals. The IgG and IgA can also retard the growth rate of crystals through adsorption. So, the incremental lines are likely to be caused, at least in part, by the accumulation of IgG and IgA on the surface of dental calculus (Lindskog and Friskopp, 1983). Despite these findings, the exact role of these molecules in plaque mineralization remains obscure.

It was found that albumin could bind to HAP surfaces and inhibit crystal growth in vitro (Robinson et al., 1998), indicating the possibility that albumin may be involved in the inhibition of crystal growth in dental plaque.

In addition to these salivary proteins, pyrophosphate and zinc ions act as crystal growth inhibitors (discussed in a later section).

\section{(H) ORGANIC ACID AND CALCULUS FORMATION}

Numerous plaque bacteria produce organic acids through degradation of carbohydrates. The roles of organic acids in caries formation have been investigated by many investigators. However, a correlation between organic acids and dental calculus has seldom been reported. Despite that fact, our knowledge of dental caries can lead one to assume the potential role of organic acids in calculus formation, since both the enamel and supragingival calculus contain apatites and have similar oral environments.

The importance of lactic acid in demineralization of enamel is well-known. Other weak acids, however, also play a role in caries formation. As Featherstone and Rodgers (1981) observed, acetic, propionic, isobutyric, and succinic acids could produce subsurface caries-like lesions similar to those produced with lactic acid. It has been proposed that the unionized form of high pKa organic acid, such as acetic, butyric, and propionic acids, diffuse most rapidly into enamel compared with the ionized from of low pKa organic acids. As the un-ionized organic acids diffuse, they continually dissociate partially into hydrogen ions and acid anions. The released hydrogen ions attack the enamel crystals. Collectively, the process of demineralization is composed of the following three steps: diffusion of the un- ionized acids into enamel, partial dissolution of acids, and diffusion of calcium and phosphate out of enamel (Featherstone and Rodgers, 1981).

The preferential diffusion of high $\mathrm{pKa}$ organic acid into enamel was confirmed by Geddes et al. (1984). Enamel slices were immersed in a solution containing acetic acid and lactic acid. Dental plaque was not used in this system, to eliminate the possibility of acid loss other than into the enamel (such as bacterial utilization). The results showed that the acetate concentration decreased linearly with time, whereas lactate concentration did not change beyond experimental error. Since there was no dental plaque in this system, the only place where the acetate could have gone is into the enamel.

Importantly, the preferential diffusion of high pKa organic acid may also apply to our understanding of the effects of organic acids on the dental calculus formation. One could assume that the un-ionized, high $\mathrm{pK}_{\mathrm{a}}$ organic acids diffuse into dental calculus, dissolve the calcium phosphate crystals, and counteract the calculus calcification.

\section{(I) ENZYMES DEGRADING CALCIFICATION INHIBITORS}

According to a study by Watanabe et al. (1982), calculus level was positively correlated with protease activity in human saliva. In addition, supragingival plaque from calculus formers has also been found to show significantly higher protease activity than that from non-calculus formers (Morita and Watanabe, 1986). These findings are understandable, since protease in saliva and plaque can degrade calcification inhibitors such as statherin and PRP. Moreover, proteases may increase dental plaque $\mathrm{pH}$ through the production of ammonia, one of the proteolytic end- products of proteins (Frostell and Söder, 1970).

Acid and alkaline phosphatases are present in oral microorganisms, dental plaque, dental calculus, and saliva (Bercy 
and Vreven, 1979). Acid and alkaline phosphatases may promote crystal growth by degrading pyrophosphate, which is an inhibitor of crystal growth and will be discussed in a later section (Francis, 1969). They hydrolyze phosphoproteins to produce inorganic phosphate ions (Poirier and Holt, 1983) and transport inorganic phosphate ions (Melani et al., 1967) for mineralization. The levels of alkaline phosphatases in bones increase where mineralization occurs (Martland and Robinson, 1924), indicating a close relationship of alkaline phosphatases with biomineralization. In the field of dentistry, a positive correlation has been found between the amounts of dental calculus and salivary phosphatases (Bercy and Vreven, 1979).

Like phosphatase, acid and alkaline pyrophosphatases can also promote crystal growth by hydrolyzing pyrophosphate. The presence and activity of pyrophosphatases in plaque and calculus have been demonstrated (Pellat and Grand, 1986). Alkaline pyrophosphatase activity occurring in dental plaque is positively correlated with calculus formation in vivo (Bercy and Vreven, 1979), despite the fact that the $\mathrm{pH}$ of dental plaque does not favor alkaline pyrophosphatase activity ( $\mathrm{pH}$ optimum, 8.5). A positive correlation between calculus formation and acid pyrophosphatase activity of saliva has also been observed (Bercy and Vreven, 1979). Importantly, a magnesium pyrophosphate complex appears to be the real substrate for pyrophosphatase, based upon the findings that pyrophosphatase activity is substantially decreased in the absence of magnesium and completely inhibited by calcium (Pellat and Grand, 1986).

\section{(J) CAlCification PROMOTERS}

\section{(1) Urea}

Urea is a product from the metabolism of nitrogen-containing substances. Urea can be secreted in normal saliva at concentrations of between 5 and $10 \mathrm{mmol} / \mathrm{L}$ (Macpherson and Dawes, 1991), but can be as high as $30 \mathrm{mmol} / \mathrm{L}$ in patients with renal disease (Peterson et al., 1985). Gingival crevicular fluid contains up to $60 \mathrm{mmol} / \mathrm{L}$ urea (Golub et al., 1971). It has been demonstrated that urease is responsible for bacterial urea hydrolysis (Sissons et al., 1995). At a neutral pH, urea is hydrolyzed by urease to $\mathrm{NH}_{4}{ }^{+}$and bicarbonate (Sissions et al., 1985). At an acidic $\mathrm{pH}$, aqueous and gaseous carbon dioxide equilibrate with bicarbonate, while, at an alkaline $\mathrm{pH}$, aqueous and gaseous $\mathrm{NH}_{3}$ co-exists with $\mathrm{NH}_{4}{ }^{+}$(Sissons et al., 1994b).

\section{(a) The effect of urea metabolism on plaque $\mathrm{pH}$}

Ammonia produced from ureolysis of urea contributes to an increased plaque $\mathrm{pH}$ that is an essential factor in natural calculus formation. A urea-induced $\mathrm{pH}$ response, which was the inverse of the Stephan $\mathrm{pH}$ curve induced by sucrose, has been observed in an in vitro biofilm culture system called "artificial mouth" (discussed in a later section) (Sissons et al., 1991). The curve of a urea-induced $\mathrm{pH}$ response contains two parts-a rising part and a return part; that is, following the application of urea to plaque, plaque $\mathrm{pH}$ rises quickly and then returns slowly to the level before the urea application.

In the "artificial mouth", when supplemented with urea, sucrose-dependent $\mathrm{pH}$ responses in the microcosm plaque shift to a more alkaline range and result in a higher resting $\mathrm{pH}$ than in that without urea supplementation (Sissons et al., 1998). Urea metabolism can also contribute to the $\mathrm{pH}$ gradient in plaque, because the diffusion and removal of ammonia are very slow (Sissons et al., 1994a). When urea is initially applied to a plaque, the plaque bacteria produce ammonia through urease, and ammonia accumulates on the plaque surface due to the slow removal and diffusion of ammonia. At this point, the $\mathrm{pH}$ gradient ranges from low at the "artificial mouth" plaque base to high at the surface. During the following minutes, some ammonia diffuses and arrives at the middle-layer plaque, and this leads to an increase in the $\mathrm{pH}$ at the middle layer. Meanwhile, some ammonia is removed from the plaque surface. Both the diffusion into plaque and the removal of ammonia decrease the $\mathrm{pH}$ at the surface. Therefore, the midplaque-to-surface $\mathrm{pH}$ gradient gradually reverses. As ammonia continuously diffuses inside the plaque, $\mathrm{pH}$ at the base gradually increases and becomes the highest. The $\mathrm{pH}$ at the base remains high for hours, and then $\mathrm{pH}$ in all layers in the plaque slowly returns to the resting $\mathrm{pH}$ level. The ureolytic $\mathrm{pH}$ response is roughly proportional to the urea concentration (Sissons et al., 1994a). The ureolytic $\mathrm{pH}$ response (an increase in plaque $\mathrm{pH}$ by the production of ammonia from urea) promotes calculus formation by increasing the saturation degree of calcium phosphate in plaque fluid. (The mechanism is discussed in a previous section.)

\section{(b) The effect of salivary flow rate on urea-dependent $\mathrm{pH}$ response in plaque}

In the oral cavity, urea available to supragingival plaque bacteria comes from both saliva and extra-oral factors such as urea-containing chewing gum and toothpastes. The effects of salivary flow rate on the $\mathrm{pH}$ responses induced by urea from these two sources are different. In the absence of exogenous urea, increased salivary flow rate promotes the urea-dependent $\mathrm{pH}$ response in plaque. Although a negative correlation has been demonstrated between salivary flow rate and urea concentration in whole saliva (Macpherson and Dawes, 1991) and parotid saliva (Shannon and Prigmore, 1960), higher flow rate means that more urea is available to dental plaque bacteria, because the effects of low urea concentrations are outweighed by an increased availability of urea. Thus, the sites with higher salivary film velocity have an increased ureadependent $\mathrm{pH}$ response in plaque (Shannon and Prigmore, 1960). That can partially explain the site-specificity of calculus distribution in the dentition.

Sissons et al. (1994a), using an "artificial mouth", investigated the effect of flow rate of a basal medium containing $0.25 \%$ mucin (BMM) on urea-induced $\mathrm{pH}$ responses in plaques. In the "artificial mouth", BMM works as artificial saliva. It was found that increasing the BMM flow rate significantly decreased the urea-induced $\mathrm{pH}$ response with respect to the maximum $\mathrm{pH}$ reached and $\mathrm{pH}$ curve area (representing the total amount of ammonia produced). The reduced $\mathrm{pH}$ response can be explained by urea dilution caused by an increasing BMM flow. Additionally, the urea- induced $\mathrm{pH}$ response varies more quickly with BMM flow rate when the flow rate is lower, indicating that ammonia clearance may be limited at higher flow rates.

\section{(c) Bacteria responsible for the ureolysis in dental plaque}

According to Frostell (1960), none of the known species of oral ureolytic bacteria contributes significantly to plaque urolysis, and most plaque ureolysis is due to an unknown but highly active sub-population of the total ureolytic flora. However, in a study by Sissons et al. (1988a), using "artificial mouth" plaque, the ureolyt- 
ic fraction of the flora detected on urea-agar plates explained $86 \%$ of the plaque urea metabolism rate. The plaque bacteria giving strong ureolytic reactions on agar plates were all Gram-positive cocci, and in 6 of the 9 plaques were streptococci only. Since Gram-positive cocci, mainly streptococci, comprise a high proportion of the total ureolytic flora, the hypothesis that plaque ureolysis is derived mainly from an unidentified active segment of the total ureolytic flora is rejected. Bacteria suspected of having a role in ureolysis include $S$. salivarius, coagulase-negative staphylococci (CNS) (Sissons et al., 1988a,b), Actinomyces viscosus/naeslundii (Gallagher et al., 1984), transient Enterobacteriaciae, unknown anaerobes (Frostell, 1960), and Haemophilus sp. (Salako and Kleinberg, 1989). Among these ureolytic bacteria, S. salivarius has attracted the most attention. It has been accepted that $S$. salivarius is a major contributor to ureolysis in natural saliva (Sissons et al., 1989) and in artificial plaque cultured from saliva (Sissons et al., 1988a,b). Although S. salivarius is regarded as a minor component of mature plaques, its number is sufficient to enable it to play a major potential role in ureolysis in plaque (Denepitiya and Kleinberg, 1982).

\section{(2) Fluoride and calculus formation}

The caries-inhibiting ability of fluoride is well-known. Fluoride not only counteracts demineralization of hard tissue through the formation of lower-solubility fluorapatite by fluoride substitution for hydroxyl ions and adsorption onto apatite surfaces (Wong et al., 1987), but also contributes to remineralization by precipitation of a fluoride-enriched apatite or calcium fluoride (Nelsons et al., 1984). Moreover, fluoride has been found to curtail greatly or even eliminate the appearance of OCP-like precursor phases during spontaneous calcium phosphate precipitation. In other words, fluoride may promote the maturation of spontaneous precipitated calcium phosphate at physiological $\mathrm{pH}$ by reducing the stability of OCP (Eanes and Meyer, 1978). Fluoride has also been demonstrated to affect the morphology of the apatite crystals as it converts them from thin plates to short and slender needles (Eanes and Meyer, 1978).

Fluoride has an antimicrobial function: A mixed culture with 19 ppm fluoride can inhibit the growth of $S$. mutans (Marsh and Bradshaw, 1990). A decreased level of S. mutans in dental plaque adjacent to fluoride-releasing glass ionomers has also been reported (Berg et al., 1990). In addition, acid production by plaque bacteria can be inhibited by the presence of fluoride (Briner and Francis, 1962). Therefore, fluoride may have the potential to increase the plaque $\mathrm{pH}$, which may be another mechanism by which fluoride inhibits demineralization and promotes remineralization of hard tissue.

Taken together, one can assume that fluoride present in saliva from the diet, toothpastes, and mouthrinses should be able to facilitate calculus formation. However, few studies or reports have shown that fluoride increases the prevalence or severity of dental calculus in humans. Instead, sodium fluoride may be able to inhibit the bacterial phosphatases and pyrophosphatases, the enzymes that are well-known to promote calculus formation (Lobene and Volpe, 1987).

\section{(3) Silicon}

Silicon is present in saliva, dental plaque, and dental calculus. The source of silicon is mainly drinking water and food. Silicic acid and silica represent most of the silicon found in drinking water and food, respectively. The family of silicic acid contains monosilicic acid and polysilicic acid. Monosilicic acid is not stable at concentrations above $2 \mathrm{mmol} / \mathrm{L}$ and may polymerize to form polysilicic acid or silica (Damen and ten Cate, 1989).

Silicic acid has been reported as a strong promoter of both spontaneous precipitation of calcium phosphates and the growth of seeded crystals (Damen and ten Cate, 1989). In a study by Damen and ten Cate (1989), silicic acid initiated spontaneous calcium phosphate precipitation earlier by reducing the induction time of precipitation. Additionally, the stimulating effect of silicic acid on the growth of seeded HAP crystals was concentration-dependent. Silicic acid was also found to stimulate the transformation from amorphous calcium phosphate to HAP (Hidaka et al., 1993). The capacity of silicic acid to promote HAP transformation stems from the presence of polysilicic acid, rather than monosilicic acid (Hidaka et al., 1993). It was found that the polysilicic-acid-containing solutions stimulated HAP transformation, whereas those containing momosilicic acid failed to do so (Hidaka et al., 1993).

Silica at a concentration of $0-2 \mathrm{mg} / \mathrm{mL}$ was reported to exert stimulating effects on calcium phosphate precipitation (Damen and ten Cate, 1989). Silica was also reported to increase the rate of calculus formation 35 days after its incorporation into food. Silica can also promote calculus formation when ingested by stomach tube. When provided via a stomach tube, silica does not promote calculus formation until 49 days after this treatment (Rølla et al., 1989). Thus, it is likely that silica may remain in plaque for a long period of time and serve as a trigger for the increase of calculus formation.

There is also epidemiological evidence for the effect of silicon on calculus formation. It has been reported that the rate of calculus formation is higher in the Indonesian than in the Norwegian population (Gaare et al., 1989). The difference in the silicon content of the food may partially explain the phenomenon. Indonesian people consume larger amounts of rice, which is enriched in silicon. The rice-based diet of Indonesian people contributes to the greater calculus formation in this population.

The calcium-binding capacity of silicic acids and silica may account for their ability to stimulate calcium phosphate precipitation. The stimulating effects may derive from the $\mathrm{OH}$-silanol groups on their surfaces, which bind cations at neutral and acid $\mathrm{pH}$ (Ruvarac, 1982). On the other hand, it is noteworthy that 3.0$30.0 \mathrm{mmol} / \mathrm{L}$ silicic acid and $10 \mathrm{mg} / \mathrm{mL}$ silica inhibit the rates of both amorphous calcium phosphate formation and HAP transformation. The inhibitory effects on calcium phosphate precipitation of silicic acid and silica at relatively high concentration may be due to their increased chelating effects.

\section{(IV) Anti-calculus Agents Used in Commercial Dentifrices}

Toothbrushing is relatively effective in dental plaque removal, but it is still inadequate for the maintenance of gingival health. Chemotherapeutic agents have been used to supplement the mechanical removal of dental plaque (Aleece and Forscher, 1954; Grossman, 1954; Zacherl et al., 1985; Volpe et al., 1992). Early attempts with chemotherapeutic agents focused on the removal of dental calculus from teeth. The use of mucinase is an example, since it was believed that enzymatic dissolution of the organic matter in calculus could help destroy the calculus structures (Aleece and Forscher, 1954). Chelating agents are known to sequester and dissolve calcium salts by forming stable and soluble calcium complexes. For instance, Ex347, a chelating 
agent, has been confirmed to effectively prevent the formation of calculus (Grossman, 1954). However, chelating agents can cause enamel damage (Weinstein and Mandel, 1964). Antimicrobial agents have also been used for calculus reduction, since micro-organisms are important for dental calculus formation. However, their usefulness is undermined because of the potential problem of developing resistance to antibiotics (Mandel, 1995). Since the 1970s, the major anti-calculus strategy has focused on inhibiting crystal growth and preventing development of mineralized plaque. At present, anti-calculus agents in use include triclosan (antimicrobial agent) with polyvinyl methyl ether (PVM) and maleic acid (MA) copolymer, and crystal growth inhibitors, including pyrophosphate with PVM/MA copolymer, zinc citrate, and zinc chloride.

Prior to a further discussion of anti-calculus agents, several important points must be elucidated. First, crystal growth inhibitors, such as pyrophosphate salts and zinc salts, have been proven effective only for the control of supragingival calculus and not for subgingival calculus. Second, the use of crystal growth inhibitors is directed at the prevention of deposit formation. Third, crystal growth inhibitors such as pyrophosphate and zinc ion typically decrease the dissolution rate of chemisorbed surfaces (Fleisch, 1981). The decrease in dissolution rate, as in the case of fluoride, could provide cariostatic benefits to treated teeth. Therefore, crystal growth inhibitors may exhibit two simultaneous functions by binding to apatite surfaces-preventing remineralization and preventing demineralization. Fourth, the currently marketed anti-calculus dentifrices and mouthrinses do not include crystal growth inhibitors alone, but also contain some form of fluoride as an anti-caries agent. Last, it is noteworthy that the concentration of crystal growth inhibitors used in dentifrices and mouthrinses is actually 2-3 orders of magnitude higher than that required for maximum coverage of growth sites on the HAP, OCP, and DCPD phases as calculated by the Langmuir analysis of crystallization rates (White et al., 1989). Overgrowth of crystals (discussed in the paragraph "Pyrophosphate and PVM/MA", below) and degradation of inhibitors have been demonstrated to impede the function of these agents. Therefore, a residual action of inhibitors retained as a "reservoir" within the plaque fluid between treatments is necessary. The residual inhibitors from the "reservoir" can coat the newly developing crystals within the plaque matrix and thus counteract the effect of overgrowth of crystals (White et al., 1989).

\section{(A) Triclosan With a PVM/MA COPOLYMer}

Triclosan is a broad-spectrum antibacterial agent active on both Gram-positive and -negative micro-organisms. The target is the cytoplasmic membrane. At bacteriostatic concentration, triclosan prevents bacterial uptake of essential amino acids, while at bactericidal concentrations, triclosan destroys the integrity of the cytoplasmic membrane and causes leakage of cellular contents (Regos and Hitz, 1974). Besides acting as an antibacterial agent, triclosan may have an anti-inflammatory function, since it can neutralize the products of bacteria that can provoke inflammation. It is also a potent inhibitor of both cyclo-oxygenase and lipoxygenase pathways (Gaffar et al., 1995).

For triclosan to be effective, a delivery system is necessary to increase its residence time in the oral cavity. PVM/MA copolymer (trade name Gantrez) has been utilized as a delivery system for triclosan. PVM/MA copolymer promotes uptake of triclosan by enamel and buccal epithelial cells (Nabi et al., 1989).
Increased retention of triclosan has also been observed in both plaque and saliva when a dentifrice containing triclosan and PVM/MA copolymer was used (Afflitto et al., 1990). The mechanism by which PVM/MA copolymer enhances the delivery of triclosan has been elucidated (Gaffar et al., 1997). The copolymer is composed of two groups: an attachment group and a solubilizing group. The solubilizing group retains triclosan in surfactant micelles so that the attachment group can have enough time to react with tooth surfaces via calcium in the liquid adherent layer. Triclosan is then slowly released via interactions with the salivary environment. In addition to the above functions, the copolymer also has weak crystal growth inhibitory property and is effective against calculus formation (Gaffar et al., 1990). The copolymer can strongly complex and sequester magnesium and therefore inhibit the hydrolysis of pyrophosphate by alkaline phosphatases (Mandel, 1992).

The effects on calculus formation of triclosan and copolymer have been substantiated by clinical studies (Volpe et al., 1992; Bánóczy et al., 1995). It was found that 0.3\% triclosan and $2.0 \% \mathrm{PVM} / \mathrm{MA}$ copolymer in a $0.243 \%$ sodium fluoride/silica base dentifrice significantly reduced the severity and occurrence of supragingival calculus after complete prophylaxis compared with placebo dentifrice.

\section{(B) Pyrophosphate AND PVM/MA COPOLYMer}

EHDP has been demonstrated as an effective inhibitor of HAP crystal growth when adsorbed onto the surfaces of HAP crystals (Francis, 1969). However, because of its hydrolytic stability in the oral cavity and its inhibitory effect on apatite nuleation (discussed in a previous section), it can interfere with normal mineralization of hard tissues (Schenk et al., 1973). Therefore, EHDP should not be used in dentifrices. Pyrophosphate is a biologically stable analog of diphosphonates in which the stable P-C-P linkage has been replaced with a labile P-O-P linkage (Fleisch et al., 1969). In contrast to EHDP, pyrophosphate is hydrolytically labile. Its hydrolytic instablility is enhanced by high temperature, low $\mathrm{pH}$, and certain enzymes (Francis, 1969). Pyrophosphate, which is present in serum and saliva, is a soluble inorganic small molecule (Stookey et al., 1989). Unlike macromolecules such as PRP, a small molecule is able to block all the adsorption sites of apatitic surface available for crystal growth, and therefore can block crystal growth even when the precipitation driving force is enhanced by the addition of fluoride (Moreno et al., 1989). Pyrophosphate is a small molecule and has been reported to inhibit crystal growth by binding to the surface of crystal. Pyrophosphate binds to two sites on the HAP surface, and one of the two sites needs to be bound by phosphate ion to permit crystal growth to occur. If this site is bound by pyrophosphate, phosphate ion cannot absorb onto crystal, and thus crystal growth is inhibited. To inhibit crystal growth effectively, the concentration of pyrophosphate has to reach a critical level. Below this level, the addition of $\mathrm{NaF}$ can induce a short period of slow precipitation, which is followed by rapid crystal growth (Moreno et al., 1989). One explanation for the induction of crystal growth by $\mathrm{NaF}$ is overgrowth of crystals. During crystal growth, the inhibitors are gradually buried by continuously growing fronts, and consequently a new surface without inhibitors is generated, and crystal growth proceeds at rates comparable with those of the control systems (in the absence of inhibitors). This phenomenon does not take place if inhibitors are macromolecules such as PRP, 
since it is difficult to bury these large molecules. In addition to the inhibitory effect on crystal growth, pyrophosphate can also delay the initiation of conversion of DCPD to HAP by over three-fold (White et al., 1989) and reduce acquired pellicle formation. It has been reported that pyrophosphate can desorb the acquired enamel pellicle, due to its ability to displace anions and negatively charged macromolecules from tooth surfaces (Rølla and Melsen, 1975).

Pyrophosphate at various concentrations has been widely used as an anti-calculus agent in dentifrices and mouthrinses. Dentifrices containing pyrophosphate have been confirmed to produce significant calculus reduction (Zacherl et al., 1985). However, pyrophosphate is susceptible to rapid breakdown in the oral cavity by bacterial and host phosphatases and pyrophosphatases. The addition of copolymer seems to be a good idea, since PVM/MA copolymer is believed to prevent hydrolysis of the pyrophosphate (Gaffar and Esposito, 1986). In clinical studies, a dentifrice containing $3.3 \%$ pyrophosphate and 1\% PVM/MA copolymer significantly inhibited the formation of supragingival calculus as compared with a placebo dentifrice (Triratana et al., 1991), and it was more effective than a dentifrice containing 3.3\% pyrophosphate alone (Schiff, 1987).

\section{(C) ZINC ION}

Zinc salts are thought to reduce plaque acidogenicity (Oppermann et al., 1980) and plaque growth in vivo (Saxton et al., 1986) and to increase resistance of HAP to acid dissolution (Brudevold et al., 1963). Zinc can also inhibit crystal growth by binding to the surfaces of solid calcium phosphates (Gilbert and Ingram, 1988). This binding is reversible and may be caused by ion exchange between zinc ions and surface calcium ions (Brudevold et al., 1963). Zinc ions also have an effect on the types and amounts of calcium phosphate crystals (Le Geros et al., 1999). Zinc at a concentration of $0.1 \mathrm{mmol} / \mathrm{L}$ inhibits the formation of DCPD, OCP, and amorphous calcium phosphate, but at higher concentrations varying from 0.5 $\mathrm{mmol} / \mathrm{L}$ to $2 \mathrm{mmol} / \mathrm{L}$, it promotes the formation of amorphous calcium phosphate or zinc-substituted tricalcium phosphate (beta-TCP), depending on the $\mathrm{pH}$ values and temperature. Additionally, the degree of crystallinity may be affected by the presence of zinc (Leskovar and Hartung, 1977).

The effect of zinc ion on calculus formation has been examined by Kazmierczak et al. (1990) in a six-month clinical study. A $2.0 \%$ zinc citrate dentifrice significantly reduced supragingival calculus deposits, compared with a placebo dentifrice. However, commercialization of dentifrice containing $2.0 \%$ zinc chloride is difficult, due to its disagreeable taste. Therefore, $0.5 \%$ zinc citrate was tested. In a three-month study, the mean calculus score (Volpe-Manhold Index) in a group using the $0.5 \%$ zinc citrate dentifrice was significantly (13.7\%) lower than that in a group using a control dentifrice (Segreto et al., 1991). However, Scruggs et al. (1991) found that a $0.5 \%$ zinc citrate dentifrice did not significantly reduce supragingival calculus. Because of these conflicting results, it would seem preferable to use a higher concentration of zinc citrate for dentifrice formulation.

\section{(D) Prevention of Calculus FORMATION IN IMPLANT PATIENTS}

Although bacterial adhesion and plaque formation on implant surfaces, especially on Ti surfaces, have been investigated in many studies (Nakazato et al., 1989; Edgerton et al., 1996), our knowledge of the plaque mineralization on implant surfaces is very limited. Theoretically, various anti-calculus agents, which were discussed above, can also be active against calculus formation on implant surfaces in addition to tooth surfaces. This needs to be confirmed by future studies.

\section{(V) Application of Biofilm Culture Systems in the Study of Plaque Mineralization}

In vivo studies of dental plaque present many difficulties. Natural dental plaque has a biodiverse, heterogeneous structure which changes over time. The oral environment is almost uncontrollable and site-specific. Therefore, it is necessary to develop in vitro culture systems which simulate the natural oral environment and are more controllable. Various biofilm culture systems have been developed in recent decades, and each system has strengths and limitations. The major oral biofilm culture system technologies in current use include chemostat-base systems (Keevil et al., 1987), a growth-rate-controlled biofilm fermenter (GRBF) (Gilbert et al., 1997), an artificial mouth (Dibdin et al., 1976), the constant-depth biofilm fermenter (CDFF) (Sarah et al., 1996), and the multiplaque artificial mouth (Sissons et al., 1991). Due to the design of the multiplaque artificial mouth, which permits the long-term independent growth of multiple replicate plaques from the same inoculum, at the same temperature, and in the same gas phases (Sissons et al., 1991), it appears to be suitable for studies of plaque growth, metabolism, plaque $\mathrm{pH}$, and mineralization (Sissons et al., 1991). The use of LabVIEW ${ }^{\circledR}$ software on a Macintosh computer makes it easier to control separate delivery of nutrients, reagents, and gas required for the culture of multiple dental plaque as well as continuous acquisition of $\mathrm{pH}$ data (Wong et al., 1994). Urea metabolism, which is closely associated with plaque mineralization, has been investigated in studies where the multiplaque artificial mouth system was used to detect the ureolytic bacteria and to examine the properties of urea metabolism in microcosm plaques. According to a study by Sissons et al. (1988b), ureolytic bacteria could be detected on Christiensen's urea-agar plates or urea segregation agar. On the two plates, colonies growing rapidly to $0.5 \mathrm{~mm}$ or larger are assumed to be involved in ureolytic activity. Moreover, the average rate of ureolysis of microcosm plaques is similar to that in natural plaques (Sissons et al., 1988b). Therefore, the validity of the multiplaque artificial mouth system in the study of urea metabolism is further reinforced. In other studies where the multiplaque artificial mouth was used (Sissons et al.,1988a, 1990, 1994a,b), the effects of $\mathrm{pH}$, bicarbonate, carbon dioxide, ammonia, and glucose on bacterial urease levels were examined. Urea-induced $\mathrm{pH}$ responses and intra-microcosm plaque $\mathrm{pH}$ gradient were observed and discussed. Furthermore, regulation of urease level in microcosm plaque became possible by controlled applications of urea, ammonia, and arginine (Sissons et al., 1995). Direct studies of microcosm plaque mineralization were also performed (Pearce and Sissons, 1987; Pearce et al., 1991; Sissons et al., 1991; Wong, 1998), and a urea- based calcium-phosphate-monofluorophosphate-urea (CPMU) mineralization solution was used for plaque mineralization research (Sissons et al., 1991; Wong, 1998).

\section{(VI) Future Research on Supragingival Calculus}

There have been many advances in our understanding of how plaque and microbial mineralization is initiated and regulated by various inhibitors and promoters, and how it can be con- 
trolled and prevented. However, there are many questions left to be answered. The roles of macromolecules, such as PRPs, statherins, immunoglobulins, and other glycoproteins, in the initiation of biomineralizaiton remain incompletely understood. The potential effects of fluoride on calculus formation need to be clarified. More studies on ureolytic bacteria, which contribute to the increase in plaque $\mathrm{pH}$, are also recommended. Development of biofilm culture systems, notably the "artificial mouth", could lead to breakthroughs in our understanding of mineralization mechanisms. In the "artificial mouth", various antibacterial agents, which may be used in future dentifrices and mouthrinses, can be evaluated with regard to their possible inhibitory effects on plaque and calculus formation. The effects of the various anti-calculus agents on plaque mineralization on implant surfaces also need to be confirmed. In addition, safer and more effective calculus control formulations should be a long-term goal in this field.

\section{Acknowledgment}

We are grateful for the finandial support of the CERG grant (a/c 10202943.21900.08009.324.01) of the Research Grant Coundil of Hong Kong and CRC grant (a/c 10203775), TheUniversity of Hong Kong, for this work.

\section{REFERENCES}

Abe M (1982). Oxides and dihydrous oxides of multivalent metals as inorganic ion exchangers. Inorganic ion exchange materials. Boca Raton, FL: CRC Press, pp. 161-273.

Afflitto J, Patel M, Smith KA, Gaffar A (1990). ${ }^{113} \mathrm{Cd}$ NMR study of the inhibitory effect of PVM/MA copolymer (Gantrez) on the alkaline phosphatase of E. coli (abstract). J Dent Res 69(Spec Iss):118.

Aleece AA, Forscher BK (1954). Calculus reduction with a mucinase dentifrice. J Periodontol 25:122-125.

Amano A, Sharma A, Lee JY, Sojar HT, Raj PA, Genco RJ (1996). Structural domains of Porphyromonas gingivalis recombinant fimbrillin that mediate binding to salivary proline-rich protein and statherin. Infect Immun 64:1631-1637.

Baier R (1982). Conditioning surface to suit the biomedical environment: recent progress. J Biomech Eng 104:257-271.

Bánóczy J, Sari K, Schiff T, Petrone M, Davies R, Volpe AR (1995). Anticalculus efficacy of three dentifrices. Am J Dent 8:205-208.

Barone JP, Nancollas GH (1978). The seeded growth of calcium phosphates, the kinetics of growth of dicalcium dihydrate on enamel, dentin, and calculus. J Dent Res 57:153-161.

Benga G, Holmes RP (1984). Interactions between components in biological membranes and their implications for membrane function. Prog Biophys Molec Biol 43:195-257.

Bennick A, Cannon M, Madapallimattam G (1979). The nature of the hydroxyapatite-binding sites in salivary acidic prolinerich proteins. Biochem J 183:115-126.

Bercy P, Vreven J (1979). Correlation between calculus index and acid and alkaline pyrophosphatases activities of dental plaque and saliva. J Biol Buccale 7:31-36.

Berg JH, Farrell JE, Brown LR (1990). Class II glass ionomer/silver cement restorations and the effect on interproximal growth of mutans streptococci. Pediatr Dent 12:20-23.

Bishop DG (1971). The distribution and function of lipids in cells. In: Biochemistry and methodology of lipids, Johnson AR, Davenport JB, editors. New York: J. Wiley and Sons, pp. $424-456$
Bollen CML, Papaioannou W, Van Eldere J, Schepers E, Quirynen M, Van Steenberghe D (1996). The influence of abutment surface roughness on plaque accumulation and peri-implant mucositis. Clin Oral Implant Res 7:201-211.

Boyan BD, Boskey AL (1984). Co-isolation of proteolipids and calcium-phospholipid-phosphate complexes. Calcif Tissue Int 36:214-218.

Briner WW, Francis MD (1962). The effect of enamel fluoride on acid production by Lactobacillus casei. Arch Oral Biol 7:541-550.

Brooks W, Demuth DR, Gil S, Lamont RJ (1997). Identification of a Streptococcus gordonii ssp B domain that mediates adhesion to Porphyromonas gingivalis. Infect Immun 65:3753-3758.

Brown CM, Hancock EB, O'Leary TJ, Miller CH, Sheldraker MA (1991). A microbiological comparison of young adults based on relative amounts of subgingival calculus. J Periodontol 62:591-597.

Brown WH, Schilling K, Giertsen E, Pearson S, Lee SF, Bleiweis A, et al. (1991). Role of a cell surface-associated protein in adherence and dental caries. Infect Immun 59:4606-4609.

Brudevold F, Steadman LT, Spinelli MA, Amdur BH, Gron P (1963). A study of zinc in human teeth. Arch Oral Biol 8:135144.

Carey C, Gregory T, Rupp W, Tatevossian A, Vogel GL (1986). The driving force is human dental plaque fluid for demineralization and remineralization of enamel mineral. In: Factors relating to demineralization and remineralization of the teeth. Leach SA, editor. Oxford: IRL Press Ltd., pp. 163-173.

Chen C (2001). Periodontitis as a biofilm infection. CA Dent Assoc J 29:362-369.

Cisar JO, Kolenbrander PE, McIntire FC (1979). Specificity of coaggregation reactions between human oral streptococci and strains of Actinomyces viscosus or Actinomyces naeslundii. Infect Immun 24:742-752.

Collins LM, Dawes C (1987). The surface area of the adult human mouth and thickness of the salivary film covering the teeth and oral mucosa. J Dent Res 66:1300-1302.

Cookson AL, Handley PS, Jacob AE, Eatson GK, Allison C (1995). Coaggregation between Prevotella nigrescens and Prevotella intermedia with Actinomyces naeslundii strains. FEMS Microbiol Lett 132:291-296.

Corbett TL, Dawes C (1998). A comparison of the site-specificity of supragingival and subgingival calculus deposition. $J$ Periodontol 69:1-8.

Cotton FA, Wilkinson G (1966). Advanced inorganic chemistry. A comprehensive text. New York: Interscience Publications. A Division of John Wiley and Sons, pp. 158-166.

Damen JJ, ten Cate JM (1989). The effect of silicic acid on calcium phosphate precipitation. J Dent Res 68:1355-1359.

Darzins A (1994). Characterization of a Pseudomonas aeruginosa gene cluster involved in pilus biosynthesis and twitching motility: sequence similarity to the chemotaxis proteins of enterics and the gliding bacterium Myxococcus xanthus. Mol Microbiol 11:137-153.

Davies DG, Parsek MR, Pearson JP, Iglewski BH, Costerton JW, Greenberg EP (1998). The involvement of cell-to- cell signals in the development of a bacterial biofilm. Science 280:295-298.

Dawes C (1998). Recent research on calculus. NZ Dent J 94:60-62.

Dawes C, Watanabe S, Biglow-Lecomte P, Dibdin GH (1989). Estimation of the velocity of the salivary film at some different location in the mouth. J Dent Res 68:1479-1482.

Denepitiya L, Kleinberg I (1982). A comparison of the microbial composition of pooled human dental plaque and salivary 
sediment. Arch Oral Biol 27:739-745.

Dibdin GH, Shellis RP, Wilson CM (1976). An apparatus for the continuous culture of micro-organisms on solid surfaces with special reference to dental plaque. J Appl Bacteriol 40:261-268.

Donald JW (1997). Dental calculus: recent insight into occurrence, formation, prevention, removal and oral health effects of supragingival and subgingival deposits. Eur J Oral Sci 105:508-522,

Eanes ED, Meyer JL (1978). The influence of fluoride on apatite formation from unstable supersaturated solutions at $\mathrm{pH}$ 7.4. J Dent Res 57:617-624.

Edgerton M, Lo SE, Scannapieco FA (1996). Experimental salivary pellicles formed on titanium surfaces mediate adhesion of streptococci. Int J Oral Maxillofac Implants 11:443-449.

Featherstone JD, Rodgers BE (1981). Effect of acetic, lactic and other organic acids on the formation of artificial carious lesions. Caries Res 15:377-385.

Fisher SJ, Prakobphol A, Kajisa L, Murray PA (1987). External radiolabelling of components of pellicle on human enamel and cementum. Arch Oral Biol 32:509-517.

Fleisch H (1981). Inhibitions of calcium phosphate precipitation and their role in biological mineralization. J Crystal Growth 53:120-134.

Fleisch H, Graham R, Russell RGG, Francis MD (1969). Diphosphonates inhibit hydroxyapatite dissolution in vitro and bone resorption in tissue culture and in vivo. Science 165:1262-1264.

Fleisch H, Russell RGG, Bisaz S, Mühlbauer RC, Williams DA (1970). The inhibitory effect of phosphonates on the formation of calcium phosphate crystals in vitro and on aortic and kidney calcification in vivo. Eur J Clin Invest 1:12- 18.

Francis MD (1969). The inhibition of calcium hydroxyapatite crystal growth by polyphosphates. Calcif Tissue Res 3:151-162.

Friskopp J (1983). Ultrastructure of nondecalcified supragingival and subgingival calculus. J Periodontol 54:542-550.

Friskopp J, Hammarström L (1980). A comparative, scanning electron microscopic study of supragingival and subgingival calculus. J Periodontol 51:553-562.

Friskopp J, Isacsson C (1984). A quantitative microradiographic study of mineral content of supragingival and subgingival dental calculus. Scand J Dent Res 92:25-32.

Frostell G (1960). Studies on the ammonia production and the ureolytic activity of dental plaque material. Acta Odontol Scand 18:29-65.

Frostell G, Söder PÖ (1970). The proteolytic activity of plaque and its relation to soft tissue pathology. Int J Dent 20:436-450.

Gaare D, Rølla G, van der Ouderaa (1989). Comparison of the rate of formation of supragingival calculus in an Asian and a European population. In: Recent advances in the study of dental calculus. Oxford: IRL Press at Oxford University Press.

Gaffar A, Esposito A (1986). Evaluation of a copolymer as an anticalculus agent (abstract 771). J Dent Res 65(Spec Iss):409.

Gaffar A, Esposito A, Afflitto J (1990). In vitro and in vivo anticalculus effects of a triclosan/copolymer system. Am J Dent 3(Spec Iss):S37-S42.

Gaffar A, Scherl D, Afflitto J, Coleman EJ (1995). The effect of triclosan on mediators of gingival inflammation. J Clin Periodont 22:480-484.

Gaffar A, Afflitto J, Nabi N (1997). Chemical agents for the control of plaque and plaque microflora: an overview. Eur J Oral Sci 14:502-507.

Gallagher IH, Pearce EI, Hancock EM (1984). The ureolytic microflora of immature dental plaque before and after rinsing with a urea-based mineralizing solution. J Dent Res 63:1037-1039.

Ganeshkumar N, Hannam PM, Kolenbrander PE, McBride BC (1991). Nucleotide sequence of a gene coding for a salivabinding protein (SsB) from Streptococcus sanguis 12 and possible role of the protein in coaggregation with actinomyces. Infect Immun 59:1093-1099.

Geddes DA, Weetman DA, Featherstone JD (1984). Preferential loss of acetic acid from plaque fermentation in the presence of enamel. Caries Res 18:430-433.

Gilbert P, Das J, Foley I (1997). Biofilm susceptibility to antimicrobials. Adv Dent Res 11:160-167.

Gilbert RL, Ingram GS (1988). The oral disposition of zinc following the use of an anticalculus toothpaste containing $0.5 \%$ zinc citrate. J Pharm Pharmacol 40:399-402.

Goldfine H (1972). Comparative aspects of bacterial lipids. In: Advances in microbial physiology. Vol. 8. Rose AH, Tempest DW, editors. New York: Academic Press, pp. 1-58.

Golub LM, Borden SM, Kleinberg I (1971). Urea content of gingival crevicular fluid and its relation to periodontal disease in humans. J Periodontal Res 6:243-251.

Grenier D, Mayrand D (1987). Functional characterization of extracellular vesicles produced by Bacteroides gingivalis. Infect Immun 55:111-117.

Grossman LI (1954). Clinical evaluation of a salivary calculus preventive agent. Oral Surg Med Oral Pathol 7:607- 608.

Hauster H, Chapman D, Dawson RM (1969). Physical studies of phospholipids XI. $\mathrm{Ca}^{2+}$ binding to monolayers of phosphatidlserine and phosphatidyl inositol. Biochim Biophys Acta 183:320-333.

Hauster H, Philips MC, Barratt MD (1975). Differences in the interaction of inorganic and organic (hydrophobic) cations with phosphatidyl serine membranes. Biochim Biophys Acta 413:341-353.

Hidaka S, Okamoto Y, Abe K (1993). Possible regulatory roles of silicic acid, silica and clay minerals in the formation of calcium phosphate precipitates. Arch Oral Biol 38:405-413.

Howell R, Boyan-Salyers B (1980). Composition of calcification between Bacterionema matruchotii and Actinomyces naeslundii. J Dent Res 59:1999-2005.

Jenkinson HF (1992). Adherence, coaggregation, and hydrophobicity of Streptococcus gordonii associated with expression of cell surface lipoproteins. Infect Immun 58:14291436.

Jensen AT, Danø M (1954). Crystallography of dental calculus and the precipitation of certain calcium phosphates. J Dent Res 33:741-750.

Johnsson M, Richardson CF, Bergey EJ, Levine MJ, Nancollas GH (1991). The effects of human salivary cystatins and statherin on hydroxyapatite crystallization. Arch Oral Biol 36:631-636.

Kazmierczak M, Mather M, Ciancio S, Fischman S, Cancro L (1990). A clinical evaluation of anticalculus dentifrices. Clin Prev Dent 12:13-17.

Keevil CW, Bradshaw DJ, Dowsett AB, Feary TW (1987). Microbial film formation: dental plaque deposition on acrylic tiles using continuous culture techologies. J Appl Bacteriol 62:129-138.

Kleerebezem M, Quadri LE, Kuipers OP, de Vos WM (1997). Quorum sensing by peptide pheromones and two- component signal-transduction systems in Gram-positive bacteria. Mol Microbiol 24:895-904. 
Lagerlöf F (1983). Effect of flow rate and $\mathrm{pH}$ on calcium phosphate saturation in human parotid saliva. Caries Res 17:403-411.

Lamkin MS, Arancillo AA, Oppenheim FG (1996). Temporal and compositional characteristics of salivary protein adsorption to hydroxyapatite. J Dent Res 75:803-808.

Le Geros RZ, Bleiwas CB, Retino M, Rohanizadeh R, Le Geros JP (1999). Zinc effect on the in vitro formation of calcium phosphates: relevance to clinical inhibition of calculus formation. Am J Dent 12:65-71.

Lear JD, Wasserman ZR, DeGrado WF (1988). Synthetic amphiphilic peptide models for protein ion channels. Science 27:1177-1181.

Leskovar P, Hartung R (1977). Inhibition of nucleation and growth of calcium oxalate crystals by aluminium, iron (II), lanthanum, cerium, neodynium, yttrium, europium, magnesium and zinc ions. Fortschr Urol Nephrol 9:30-34.

Lindskog S, Friskopp J (1983). Immunoglobulins in human dental calculus demonstrated with the peroxidase- antiperoxidase (PAP) method. Scand J Dent Res 91:360-364.

Listgarten MA (1987). Nature of periodontal disease: pathogenic mechanisms. J Periodontal Res 22:172-178.

Little MF, Hazen SP (1964). Dental calculus composition (2); subgingival calculus, ash, calcium and sodium. J Dent Res 43:654-651.

Little MF, Bowman L, Cascinani CA, Rowley J (1966). The composition of dental calculus 111; supragingival calculus-the amino acid and saccharide component. Arch Oral Biol 11:385386.

Lobene RR, Volpe AR (1987). The anti-calculus effect of dentifrices containing pyrophosphate salts and sodium fluoride. Compend Contin Educ Dent 8(Suppl 8):S272-274.

Macpherson LMD, Dawes C (1991). Urea concentration in minor mucous gland secretions and the effect of salivary film velocity on urea metabolism by Streptococcus vestibularis in an artificial plaque. J Periodontal Res 26:395-401.

Maitland M, Robinson R (1924). The possible significance of hexose phosphoric esters in ossification. V. The enzymes in the early stages of bone development. Biochem J 18:1354-1357.

Mandel ID (1957). Histochemistry of calculus formation. J Periodontol 28:132-137.

Mandel ID (1992). Rinses for the control of supragingival calculus formation. Int Dent J 42:270-275.

Mandel ID (1995). Calculus update: prevalence, pathogenicity and prevention. J Am Dent Assoc 126:573-580.

Mandel ID, Eisenstein A (1969). Lipids in human salivary secretion and salivary calculus. Arch Oral Biol 14:231-233.

Mandel ID, Levy BM, Wasserman BH (1957). Histochemistry of calculus formation. J Periodontol 28:132-137.

Margolis HC, Varughese K, Moreno EC (1982). Effect of fluoride on crystal growth of calcium apatites in the presence of a salivary inhibitor. Calcif Tissue Int 34:S33-S40.

Marsh PD, Bradshaw DJ (1990). The effect of fluoride on the stability of oral bacterial communities in vitro. J Dent Res 69:668-671.

McIntire FC, Vatter AE, Baros J, Arnold J (1978). Mechanism of coaggregation between Actinomyces viscosus $\mathrm{T} 14 \mathrm{~V}$ and Streptococcus sanguis 34. Infect Immun 21:978-988.

Melani F, Ramponi G, Farnanaro M (1967). Regulation by phosphate of alkaline phosphatase in rat kidney. Biochim Biophys Acta 138:411-420.

Moorer WR, ten Cate JM, Buijs JF (1993). Calcification of a cario- genic Streptococcus and of Corynebacterium (Bacterionema) matruchotii. J Dent Res 72:1021-1026.

Moreno EC, Aoba T, Gaffar A (1989). Physical chemistry of calculus formation. In: Recent advances in the study of dental calculus. Oxford: IRL Press at Oxford University Press, pp. 129-142.

Morita M, Watanabe T (1986). Relation between the presence of supragingival calculus and protease activity in dental plaque. I Dent Res 65:703-705.

Morrison DA (1997). Streptococcal competence for genetic transformation: regulation by peptide pheromones. Microb Drug Resist 3:27-37.

Nabi N, Mukerjee C, Schmid R, Gaffar A (1989). In vitro and in vivo studies on triclosan/PVM/MA copolymer NaF combination as an anti-plaque agent. Am J Dent 2:197-206.

Nakazato G, Tsuchiya H, Sato M, Yamauchi M (1989). In vivo plaque formation on implant materials. Int J Oral Maxillofac Implants 4:321-326.

Nakou M, Mikx FHM, Oosterwaal PJM, Kruijsen JCWM (1987). Early microbial colonization of permucosal implants in edentulous patients. J Dent Res 66:1654-1657.

Nelsons DGA, Jongebloed WL, Arends J (1984). Crystallographic structure of enamel surfaces treated with topical fluoride agents: TEM and XRD considerations. J Dent Res 63:6-12.

O'Toole GA, Kolter R (1998). Flagella and twitching motility are necessary for Pseudomonas aeruginosa biofilm development. Mol Microbiol 30:295-304.

Oppenheim FG, Yang YC, Diamond RD, Hyslop D, Offner GD, Troxler RF (1986). The primary structure and functional characterization of the neutral histidine-rich polypeptide from human parotid saliva. J Biol Chem 261:1177- 1182

Oppermann R, Rølla G, Johansen J (1980). Thiol groups and reduced acidogenicity of dental plaque in the presence of metal ions in vivo. Scand J Dent Res 88:389-396.

Parfitt G (1959). A survey of the oral health of Navajo Indian children. Arch Oral Biol 1:193-205.

Pearce EI, Sissons CH (1987). The concomitant deposition of strontium and fluoride in dental plaque. J Dent Res 66:15181522

Pearce EI, Wakefield J, Sissons CH (1991). Therapeutic mineral enrichment of dental plaque visualized by transmission electron microscopy. J Dent Res 70:90-94.

Pellat BP, Grand M (1986). Inorganic pyrophosphatase activity in a plaque calcifying microorganism: Bacterionema matruchotii. J Biol Buccale 14:223-228.

Peterson S, Woodhead J, Crall J (1985). Caries resistance in children with chronic renal failure: plaque $\mathrm{pH}$, salivary $\mathrm{pH}$, and salivary composition. Paediatric Res 19:796-799.

Poff AM, Pearce EI, Larsen MJ, Cutress TW (1997). Human supragingival in vivo calculus formation in relation to saturation of saliva with respect to calcium phosphates. Arch Oral Biol 42:93-99.

Poirier TP, Holt SC (1983). Acid and alkaline phosphatases of Capnocytophaga species. Isolation, purification and characterization of the enzymes from Capnocytophaga ochracea. Can J Microbiol 29:1361-1368.

Pratt LA, Kolter R (1998). Genetic analysis of Escherichia coli biofilm formation: roles of flagella, motility, chemotaxis and type I pili. Mol Microbiol 30:285-293.

Pulcini E (2001). Biofilms: sensing and signalling. CA Dent Assoc J 29:351-353.

Quirynen M, Listgarten M (1990). The distribution of bacterial morphotypes around natural teeth and titanium implants ad 
modum Brånemark. Clin Oral Implant Res 1:8-12.

Raj PA, Johnsson M, Levine MA, Nancollas GH (1992). Salivary statherin. Dependence on sequence, charge, hydrogen bonding potency, and helical conformation for adsorption to hydroxyapatite and inhibition of mineralization. J Biol Chem 267:5968-5976.

Regos J, Hitz HR (1974). Investigations on the model of action of triclosan, a broad spectrum antibacterial agent. Zbl Bakt Hyg 226:390-401.

Rice A, Hamilton MA, Camper AK (2000). Apparent surface associated lag time in growth of primary biofilm cells. Microb Ecol 40:8-15.

Robinson C, Shore RC, Bonassn A, Brooks SJ, Boteva E, Kirkham J (1998). Identification of human serum albumin in human caries lesions of enamel. The role of putative inhibitors of remineralization. Caries Res 32:193-199.

Rølla G, Melsen B (1975). Desorption of proteins and bacteria from hydroxyapatite by fluoride and monofluorophosphate. Caries Res 9:66-73.

Rølla G, Gaare D, Langmyhr FJ, Helgeland K (1989). Silicon in calculus and its potential role in calculus formation. In: Recent advances in the study of dental calculus. Oxford: IRL Press at Oxford University Press, pp. 97-104.

Rowles SL (1964). Biophysical studies on dental calculus in relation to periodontal disease. Dent Pract Dent Rec 15:2-7.

Salako NO, Kleinberg I (1989). Incidence of selected ureolytic bacteria in human dental plaque from sites with differing salivary access. Arch Oral Biol 34:787-791.

Saxton CA, Harrap G, Lloyd A (1986). The effect of dentifrices containing zinc citrate on plaque growth and oral zinc level. $J$ Clin Periodontol 13:301-306.

Scheie AA (1994). Mechanisms of dental plaque formation. Adv Dent Res 8:246-253.

Schenk R, Merz WA, Mühlbauer R, Russell RGG, Fleisch H (1973). Effect of ethane-1-hydroxy-1-diphosphonate (EHDP) and dichloromethylene diphosphonate on the calcification and resorption of cartilage and bone in the tibial epiphysis and metaphysis of rats. Calcif Tissue Res 11:196-214.

Schiff TG (1987). Comparative clinical study of two anticalculus dentifrices. Compend Suppl 8:275-277.

Scruggs RR, Stewart PW, Samuels MS, Stamm JW (1991). Clinical evaluation of seven anticalculus dentifrice formulations. Clin Prev Dent 12:23-27.

Segreto VA, Collins EM, D'Agostino R, Cancro LP, Pfeifer HJ, Gilbert RJ (1991). Anticalculus effect of a dentifrice containing $0.5 \%$ zinc citrate trihydrate. Community Dent Oral Epidemiol 19:29-31.

Shannon IL, Prigmore JR (1960). Parotid gland flow rate and parotid fluid urea concentration. Oral Surg Oral Med Oral Pathol 13:1013-1018.

Sidaway DA (1980). A microbiological study of dental calculus. IV. An electron microscopic study of in vitro calcified microorganisms. J Periodontal Res 15:240-254.

Simmonds R, Tompkins GR, George RJ (2000). Dental caries and the microbial ecology of dental plaque: a review of recent advances. NZ Dent J 96:44-49.

Sissons CH, Cutress TW, Pearce EI (1985). Kinetics and product stoichiometry ureolysis by human salivary bacteria and artificial-mouth plaque. Arch Oral Biol 30:781-790.

Sissons CH, Hancock EM, Cutress TW (1988a). The source of variation in ureolysis in artificial plaque cultured from human salivary bacteria. Arch Oral Biol 33:721-726.
Sissons $\mathrm{CH}$, Hancock EM, Perinpanayagam HE, Cutress TW (1988b). The bacteria responsible for ureolysis in artificial plaque. Arch Oral Biol 3:727-734.

Sissons CH, Loong PC, Hancock EM, Cutress TW (1989). Electrophoretic analysis of ureases in Streptococcus salivarius and in saliva. Oral Microbiol Immunol 4:211-218.

Sissons CH, Perinpanayagam HE, Hancock EM, Cutress TW (1990). pH regulation of urease levels in Streptococcus salivarius. J Dent Res 69:1131-1137.

Sissons CH, Cutress TW, Hoffman MP, Wakefield JS (1991). A multi-station dental plaque microcosm (artificial mouth) for the study of plaque growth, metabolism, $\mathrm{pH}$, and mineralization. J Dent Res 70:1409-1416.

Sissons CH, Wong L, Hancock EM, Cutress TW (1994a). The pH response to urea and the effect of liquid flow in "artificial mouth" microcosm plaques. Arch Oral Biol 39:497-505.

Sissons CH, Wong L, Hancock EM, Cutress TW (1994b). pH gradients induced by urea metabolism in "artificial mouth" microcosm plaques. Arch Oral Biol 39:507-511.

Sissons CH, Wong L, Cutress TW (1995). Regulation of urease levels in microcosm dental plaque. Microbial Ecol Health Disease 8:219-224.

Sissons CH, Wong L, Shu M (1998). Factors affecting the resting $\mathrm{pH}$ of in vitro human microcosm dental plaque and Streptococcus mutans biofilms. Arch Oral Biol 43:93-102.

Slomiany A, Slomiany BL, Mandel ID (1981). Lipid composition of human parotid saliva from light and heavy dental calculus formers. Arch Oral Biol 26:151-152.

Stookey GK, Jackson RD, Beiswanger BB, Stookey KR (1989). Clinical efficacy of chemicals for calculus prevention. In: Recent advances in the study of dental calculus. Oxford: IRL Press at Oxford University Press, pp. 235-258.

Swain LD, Boyan BD (1989). Ion-transport properties of membrane proteins associated with microbial calcification. In: Recent advances in the study of dental calculus. Oxford: IRL Press at Oxford University Press, pp. 37-46.

Theilade J, Fitzgerald RJ, Scott DB, Nylen MU (1964). Electron microscopic observations of dental calculus in germ-free rats and conventional rats. Arch Oral Biol 9:97-100.

Triratana T, Rustogi KN, Lindhe J, Volpe AR (1991). The effect of an anticalculus dentifrice on supragingival calculus formation and gingival recession in Thai adults: one-year study. J Clin Dent 3:22-26.

van Dijk S, Dean DD, Liu Y, Zhao Y, Chirgwin JM, Schwartz Z, et al. (1998). Purification, amino acid sequence, and cDNA sequence of a novel calcium-precipitation proteolipid involved in calcification of Corynebacterium matruchotii. Calcif Tissue Int 62:350-358.

van Loosdrecht MCM, Lyklema J, Norde W, Zehnder AJ (1990). Influence of interfaces on microbial activity. Microbiol Res 4:75-87.

Vogel JJ, Boyan-Salyers BD (1976). Acidic lipids associated with the local mechanism of calcification. Clin Orthop Rel Res 118:230-241.

Volpe AR, Schiff TJ, Cohen S, Petrone ME, Petrone D (1992). Clinical comparison of the anticalculus efficacy of two triclosan-containing dentifrices. J Clin Dent 3:93-95.

Watanabe T, Toda K, Morishita M, Iwamoto Y (1982). Correlations between salivary protease and supragingival or subgingival calculus index. J Dent Res 61:1048-1051.

Weinstein E, Mandel ID (1964). The present status of anticalculus agents. J Oral Ther Pharm 1:327-334. 
White DJ, Bowman WD, Nancollas GH (1989). Physical-chemical aspects of dental calculus formation and inhibition: in vitro and in vivo studies. In: Recent advances in the study of dental calculus. Oxford: IRL Press at Oxford University Press, pp. 175-188.

Williams RL, Williams DF (1988). Albumin adsorption on metal surfaces. Biomaterials 9:206-212.

Wong L (1998). Plaque mineralization in vitro. NZ Dent J 94:15-18.

Wong L, Cutress TW, Duncan JF (1987). The influence of incorporated and adsorbed fluoride on the dissolution of powered and pelletized hydroxyapatite in fluoridated and non-fluoridated acid buffers. J Dent Res 66:1735-1741.

Wong L, Sissons CH, Cutress TW (1994). Control a multiple den- tal plaque culture system and long-term, continuous, plaque pH measurement using LabVIEW ${ }^{\circledR}$. Binary 6:173-180.

Wuthier RE, Cummins JW (1974). In vitro incorporation of $\left({ }^{3} \mathrm{H}\right)$ since phospholipid of proliferating and calcifying epiphyseal cartilage and liver. Biochim Biophys Acta 337:50-59.

Zacherl WA, Pfeiffer HJ, Swancar JR (1985). The effect of soluble pyrophosphates on dental calculus in adults. J Am Dent Assoc 110:737-738.

Zhan L, Fu MD, Liu TJ, Yue SL (1998). Study on the adhesion of an endemic strain of Streptococcus mutans serotype c to acquired pellicle. II. Isolation and extraction of adhesins of an endemic strain of Streptococcus mutans serotype c. Hua Xi Kou Qiang Yi Xue Za Zhi 16:76-79. 